Finanse, Rynki Finansowe, Ubezpieczenia nr 2/2016 (80), cz. 2

\title{
The quality of information on financial liquidity - empirical evidence from public companies quoted on Warsaw Stock Exchange
}

\author{
Wojciech Hasik $^{*}$
}

\begin{abstract}
Streszczenie: Purpose - the purpose of the paper is to investigate the actual reporting practices of Polish public companies quoted on Warsaw Stock Exchange (WSE) and asses their relevance for stakeholders. This paper presents results of author's wider research on quality of financial information on liquidity provided by Polish public companies. The first part of research covered quality of information on solvency. Thus the paper can be treated as a natural continuation of research report. Design/Methodology/Approach - paper provides report from an empirical, qualitative studies over individual financial reports of companies included WIG 30. index of the biggest companies quoted on WSE. Research was made in a form of a survey. Findings - author brings evidence that public companies quoted on WSE do not provide the essential information allowing stakeholders to understand and assess their liquidity which is the most neuralgic feature of entities performance. Thus, in fact, stakeholders must judge on entities going concern without relevant information. Originality/Value - author bases his opinions on evidence from empirical research of Polish public companies' reporting practises. Empirical examination of reporting practices in Poland is still very rare, yet crucial for diagnosis and critique of it in the context of stability of financial markets and setting up directions for necessary improvements. Especially that author is taking stakeholders' perspective when assessing relevance of financial reporting practices.
\end{abstract}

Słowa kluczowe: quality of financial information, financial liquidity, financial reporting practice, Warsaw Stock Exchange

\section{Introduction}

The purpose of the paper is to examine the reporting practices of companies quoted on Warsaw Stock Exchange (hereinafter WSE) in order to assess the quality of reported information on liquidity. The paper presents segment of results of the a wider research project performed by an author aimed on diagnosis of quality of financial information presented by public companies in WSE. The selection of presented outcomes is driven by editorial limitations of this publication.

Quality of financial information is a topic quite frequently raised by researchers in Poland. However, in huge majority of cases they take a normative approach, occasionally focusing on semantics (Walińska, Jurewicz, 2008), relatively rarely take critical position (Walińska at al., 2015), and still quite rarely examining practice (Ignatowski, 2011; Dyczkowska, 2009, Mućko, 2008). It must be stressed out however, that the trend among Polish researchers is slowly but noticeably evolving over recent years towards empirical studies

\footnotetext{
* dr Wojciech Hasik, Uniwersytet Ekonomiczny we Wrocławiu, Katedra Teorii Rachunkowości i Analizy Finansowej, e-mail: wojciech.hasik@ue.wroc.pl
} 
(Klimczak et al., 2015; Hasik, 2015; Eisenschmidt, Krasodomska, 2015). Still, in author’s opinion this approach is taken by minority of researchers.

Author believes that the only relevant perspective to assess quality of financial information is the perspective of stakeholders. Similar opinions are being expressed more and more frequently, due to the fact that financial crisis discovered number of problems with relevance of financial information disclosed by public companies (Walińska at al., 2015, p. 25). Thus, in designing of research presented in this paper author refers to his personal, nearly 10 years long experience in different positions in corporate banking in the area of credit risk assessment. This track record gives a solid background for the thesis formulated by the author, that financial statements do not provide stakeholders with sufficient information both on liquidity and solvency.

\section{Liquidity relevance for stakeholders' judgements}

Financial statement should provide information useful to asses two basic dimensions of a reporting entity: financial position and performance. With regard to financial position there are two major aspects commonly analysed by stakeholders: solvency and financial liquidity.

Although the liquidity is in fact a feature of an asset (i.e. its ability to be converted into cash) it is commonly treated also as a feature of a business entity. In this context it means entity's ability to timely service its financial obligations.

Based on his professional experience Author notices that professional analysts in financial markets tend to take different position in analysing and understanding nature of liquidity than the one typically presented in reference books on financial analysis and by most academics. Professionals tend to treat liquidity as a dynamic feature of an entity, pulling it more toward dynamic performance measure than static financial position. Consequently, they use liquidity measures different from traditional liquidity ratios, based on static figures from the balance sheet only. The most typical dynamic measure of liquidity is debt service coverage ratio (DSCR). Typical liquidity ratios along with its safety benchmarks are presented in table 1.

Table 1

Most common liquidity ratios and their safety benchmarks

\begin{tabular}{lll}
\hline Ratio & Most common ratio formula & Benchmark commonly accepted as a save level \\
\hline current ratio & current assets/ current liabilities & above 1,2x \\
\hline quick ratio & $\begin{array}{l}\text { (current assets-inventories)/ current } \\
\text { liabilities }\end{array}$ & above 0,8-1,0x \\
\hline working capital & current assets - current liabilities & above zero \\
\hline DSCR & EBITDA/ financial payments & above 1,2x \\
\hline
\end{tabular}

Source: prepared by author.

DSCR is much more informative than static ratios as it confronts the available operating cash flow or its estimates with entity's financial payments. It is treated as a basic measure of entity's liquidity to such an extent that it is often called a credibility ratio. The only problem with it is that entities are hardly willing to disclose details on debt repayment schedule 
in financial reports, thus it is rarely possible to follow DSCR in making judgements on entity's liquidity. Author believes, that the research will provide verification of that thesis.

\section{Sample characteristics and research methods}

The research sample was set on the basis of WIG 30, the most important index of WSE, including 30 companies of biggest capitalization. Entities from financial sectors: banks and insurers (8 companies in total) were excluded from the sample due to specific reporting requirements and specificity of their activities and approach to liquidity perception and analysis. As WIG 30 represents the companies of biggest capitalization they are widely and frequently analyzed by numerous financial institutions providing them with different mix of financing (including banks, funds \& insurers), analysts representing brokerage houses and individual investors. Therefore, it is reasonably justified to expect these companies to present the highest standards of financial information quality.

The sample counted 22 entities from diversity of industries representing three groups:

- heavy industries (13 entities), including: primary commodities (4 entities), energetics (4 entities), chemical (3 entities) and petrochemical (2 entities),

- services (7 entities), including: retail (3 entities), broadcasting (2 entities), telecommunication and IT (1 entity each),

- other: construction and agriculture (1 entity each).

Within the sample 12 entities (55\%) were acting as financial vehicles for entire group (FINCO) that means that majority or even all debt was booked and managed from the level of a dominating company of a holding (HOLDCO). For this reason object of research was the individual, annual, audited financial statements instead of consolidated ones. The effect of that practice is noticeable predominantly in the individual financial statement, thus creating in it a need for additional disclosures in this respect in order to allow stakeholder to fully understand financial position of a holding entity and properly asses its liquidity. IFRSs were a basis of 21 examined reports, in one case report was based on Polish act on accounting.

Quality of financial statements was confirmed in all cases by unqualified opinions of independent auditors. In 20 cases financials were audited by "big 4". In 4 statements unqualified opinions were supplemented by auditors additional notices, in one case of potentially high importance for traditionally perceived liquidity ${ }^{1}$.

Means of financial ratios of solvency and liquidity are presented in table 2 below. Liquidity is presented in the context of solvency, as the indebtedness (the derivative feature of solvency) is obviously the second line driver of potential liquidity issues, especially perceived in a dynamic way (i.e. as ability to timely service financial obligations).

Sample companies are well capital equipped (high solvency levels). In case of heavy industries leverage measured by Debt/EBITDA ${ }^{2}$ ratio is significantly increased which is

\footnotetext{
${ }^{1}$ Auditor noticed improper financing structure: current liabilities exceeded current assets, which commonly is perceived as liquidity measure. Author believes, however, that this feature measures in fact solvency (expressing a static balance sheet structure) rather than liquidity which should be perceived rather as a dynamic reference to the ability of company to timely service its financial obligations).

${ }^{2}$ Debt/EBITDA is a hybrid ratio incorporating dynamic factor (EBITDA) and static (DEBT value). It is commonly used by financial institutions to indicate the general financial health of a company. Commonly accepted safety level of it should not exeed 3,0-4,0 times.
} 
understood due to capital intense activities. Surprisingly, the leverage of non-FINCOs is statistically higher than of FINCO. Statistical measures of liquidity shows that in the entire population as well as within the analysed subgroups the safety benchmarks of liquidity ratios are met. This is, however, highly misleading. Analysing the number of entities for which current liquidity ratio falls below one we can identify potential liquidity problems in case of $41 \%$ of sample. The share of companies with potential liquidity problems gets even higher (60\%) for companies not acting as a FINCO. It may suggest that FINCOs are forced to keep much higher level of financial self-discipline to be able to act as a debt arranger for entire capital group.

Table 2

Characteristic of a research sample based on means of solvency and liquidity ratios

\begin{tabular}{|c|c|c|c|c|c|c|}
\hline \multirow[t]{2}{*}{ Ratio } & \multirow{2}{*}{$\begin{array}{l}\text { Safety } \\
\text { benchmark }\end{array}$} & \multirow{2}{*}{$\begin{array}{l}\text { Entire } \\
\text { sample }\end{array}$} & \multicolumn{2}{|c|}{ industries breakdown } & \multicolumn{2}{|c|}{ is HOLDCO a FINCO } \\
\hline & & & $\begin{array}{l}\text { heavy indus- } \\
\text { tries }\end{array}$ & $\begin{array}{c}\text { services and } \\
\text { other industries }\end{array}$ & YES & $\mathrm{NO}$ \\
\hline Debt/EBITDA & $\max 3,0-4,0 x$ & $4,94 x$ & $7,81 x$ & $2,36 x$ & $4,69 x$ & $5,19 x$ \\
\hline Solvency & $\min 30 \%$ & $55 \%$ & $58 \%$ & $58 \%$ & $56 \%$ & $56 \%$ \\
\hline current ratio & $\min 1,2 x$ & $1,35 x$ & $1,47 x$ & $1,45 x$ & $1,44 \mathrm{x}$ & $1,44 \mathrm{x}$ \\
\hline quick ratio & $\min 0,8 x$ & $0,68 x$ & $0,94 x$ & $0,83 x$ & $0,72 x$ & $0,72 \mathrm{x}$ \\
\hline \multicolumn{2}{|c|}{$\begin{array}{l}\text { no. of entities (\% of sample) } \\
\text { with current ratio below } 1,0 \mathrm{x}\end{array}$} & $9(41 \%)$ & $5(38 \%)$ & $4(44 \%)$ & $3(25 \%)$ & $6(60 \%)$ \\
\hline
\end{tabular}

Source: prepared by author.

Research methods were subordinated to its goal, it is assessing the quality of financial information in range of liquidity. Thus it implicated choice of qualitative and descriptive study approach. Examination of 22 individual financial reports took form of an interview questions covering four defined dimensions of quality of financial information regarding entity's liquidity. Quality was perceived as availability and transparency of information necessary for a stakeholder to understand and asses the following elements:

1. Maturity profile and available buffers of working capital financing. In this area stakeholders should be able to understand entity's real financial position within liquidity. Analysis limited to information presented in the face of the balance sheet is often distorted by a simple trick made by financial managers within creative accounting. The trick consist in arranging the tenors of working capital financing extended up to 2 or even more years which allows companies to classify this debt as a long term liability. It does not change the fact, that this type of financing is not feasible and should not be used to finance CAPEX. However it is hugely disturbing stakeholders perception of entities liquidity position showing adequate financing structure where it is not. The stakeholders should be able to filter out these tricks by analysing the maturity profile of typical working capital financing (typically revolving or non-revolving not amortized loans or bonds). It would also allow stakeholder to identify the long term financing subject to amortization with will be directly compromising future cash flows of the entity. Another issue within this area is availability of limits for working capital accessible by an entity on demand whenever its liquidity is squeezed. Such limits, committed usually by banks, provide a liquidity reserves ready to finance temporarily increased demand for working capital. Amount 
of buffer should be adjusted to the specificity of a business model, its seasonality or other features.

2. Characteristics and repayment schedule of fixed term financing. Within this area stakeholder should be able to assess amounts of expected financial payments that must be serviced from entity's operating cash flow and assess in this way repayment capacity of it, typically throughout DSCR calculation. The crucial information necessary to perform this analysis are repayment schedules of typical, amortized term financing allowing to determine amount frequently called as: current portion of long term debt (CPLTD).

Identification of the above listed research areas was inspired by author's professional experience. The research questions investigated during the survey are presented in the following paragraph.

\section{Research results}

Research was made in the form of detailed questions covering two above identified liquidity sensitive areas. Results are presented in tables 3 and 4 below, accompanied by comments where they provide better inside of investigated issue.

\section{Table 3}

Reporting on maturity profile and availability of working capital financing

\begin{tabular}{llrrrrl}
\hline No. & Research question & Yes & No & N/A & Partially & Comment \\
\hline 1. & $\begin{array}{l}\text { Is a long term portion } \\
\text { of working capital } \\
\text { financing deter- } \\
\text { mined? }\end{array}$ & 1 & 6 & 11 & 4 & $\begin{array}{l}\text { "Partially": information is not provided, } \\
\text { however it is possible to estimate LT portion } \\
\text { of working capital financing based on other } \\
\text { information }\end{array}$ \\
\hline $2 . \quad \begin{array}{l}\text { Is a maturity of debt } \\
\text { elements disclosed? }\end{array}$ & 8 & 7 & - & 7 & $\begin{array}{l}\text { Within "No" there are 2 cases when infor- } \\
\text { mation was disclosed in management reports. } \\
\text { "Partially" - only maturity of bonds was } \\
\text { disclosed }\end{array}$ \\
\hline $3 . \quad \begin{array}{l}\text { Is an information on } \\
\text { available credit limits } \\
\text { disclosed? }\end{array}$ & 14 & 6 & - & 2 & $\begin{array}{l}\text { "N" includes 3 cases when information was } \\
\text { disclosed only in management report. "Par- } \\
\text { tially": information is not provided, however } \\
\text { it is possible to estimate }\end{array}$ \\
\hline
\end{tabular}

Source: prepared by author.

So much as $50 \%$ of sample companies negotiated extended tenors of typical working capital financing to stabilize sources of financing and improve their liquidity. Among them only one company informed about portion of LT debt securing working capital financing and in 4 cases it took detailed investigation over several notes to figure out these amounts (question 1). It was not possible at all in $55 \%$ of cases when such arrangement was made. Author diagnoses the more general problem with disclosures of financial contracts details. Companies are clearly limiting themselves to the scope of information literary listed as compulsory disclosure. So much as in $64 \%$ of cases no information on maturity of bank financing is disclosed at all (question 2). For some reasons entities differently treat bonds and report in a quite more detailed way about these contracts, whereas the same companies apply different disclosure standards for financing contracts with banks. This situation seriously limits stakeholders in possible relevant assessment of reporting entities liquidity. 
Another element of entity liquidity positon is availability of credit limits securing a liquidity buffer. In $36 \%$ of cases this information is not available in financial statement, although 2 companies provided respective disclosure in their management reports (question 3).

Clearly stakeholder faces serious obstacles trying to understand and judge on structure, maturity and availability of working capital financing.

\section{Table 4}

Reporting on repayment schedule and CPLTD

\begin{tabular}{llcrrrl}
\hline No. & Research question & Yes & No & N/A & No info & Comment \\
\hline 4. & $\begin{array}{l}\text { Is there any amortized debt } \\
\text { component present? }\end{array}$ & 15 & 4 & - & 3 & $\begin{array}{l}\text { In all 3 cases when no information } \\
\text { was disclosed there is a LT debt } \\
\text { component likely to be amortized. }\end{array}$ \\
\hline 5. & $\begin{array}{l}\text { Is the repayment schedule of LT } \\
\text { debt component disclosed? }\end{array}$ & - & 18 & 4 & - & $\begin{array}{l}\text { "No": in 1 case there was irrele- } \\
\text { vant disclosure. }\end{array}$ \\
\hline 6. & $\begin{array}{l}\text { Is the CPLTD reported in the } \\
\text { face of the balance sheet? }\end{array}$ & 2 & 16 & 4 & - & \\
\hline 7. & $\begin{array}{l}\text { Is the CPLTD disclosed in } \\
\text { notes? }\end{array}$ & 5 & 13 & 4 & $-\begin{array}{l}\text { " } Y \text { " from question 6. match, thus } \\
\text { they do not add. }\end{array}$ \\
\hline
\end{tabular}

Source: prepared by author.

Another component of liquidity positon is structure and repayment schedules of term financing. Only 4 entities clearly reported lack of amortized debt component (question 4). In remaining cases (i.e. in $82 \%$ of a sample) existence of it was either clear (15 entities) or is assumed (3 entities). None of these companies disclosed any information allowing to determine or even estimate repayment schedule of LT debt component (question 5). However, in 2 cases CPLTD was reported directly on the face of the balance sheet, separately from ST working capital financing (question 6), and in 5 cases it was disclosed in notes (question 7). As positive answers to question 6 and 7 match there are only 5 cases in total (28\% of cases where amortized debt exists) when CPLTD is identifiable allowing precise DSCR calculation. It must be stressed out, that even in these cases any estimation for subsequent years will be much less reliable without any inside to repayment schedules.

\section{Final conclusions}

Research was conducted on a small sample of companies, so its results might be assessed as questionable from statistical and formal point of view. However the qualitative selection of a sample, i.e. biggest and most respectful companies in Poland, included in WIG 30 index of WSE, representing the highest reporting standards of public companies ${ }^{3}$, is a solid reason allowing judgements on entire population. The research results clearly confirm author's professional experiences that reporting practice of companies in Poland is just not sufficient

\footnotetext{
${ }^{3}$ For all statements independent auditors, in majority of cases representing "big 4”, issued unqualified opinions and many of them were awarded in consecutive editions of the contests for the Best Annual Report prepared on the basis of IFRS, organised since 2004 by Polish Institute of Accounting and Taxes (www.irip.pl/raport_roczny).
} 
to allow a regular stakeholder who is limited to officially published financial information to reliably assess company liquidity position.

Conclusion is quite terrific. $41 \%$ of sample companies have potential liquidity problems (current ratio < 0 ). Still in $64 \%$ of cases stakeholder is not able to understand maturity profile of financial debt and the only disclosures refer to bonds (provided mostly by passive creditors), in $27 \%$ of cases there is no way to assess whether company has any liquidity buffer available. Moreover, in $78 \%$ of cases when companies must repay debt according to contractual schedules stakeholders have absolutely no possibility to judge on entities' capability to timely service these obligations. Such situation imposes critical risk to financial markets and should trigger urgent changes of reporting practices in Poland towards more transparent disclosure on liquidity sensitive areas.

\section{Literature}

Dyczkowska, J. (2009). Sprawozdawczość finansowa jako źródło informacji wspomagającej wykrywanie kryzysu w przedsiębiorstwie. Zeszyty Teoretyczne Rachunkowości, 51 (107), 5-14.

Eisenschmidt, K., Krasodomska, J. (2015). Prospective information in management commentary - a comparison between Germany and Poland. In: J. Krasodomska, K. Świetla (red.), Wspótczesne uwarunkowania sprawozdawczości $i$ rewizji finansowej (s. 103-114). Kraków: online publication of UEK downloaded from: http://rachfin.uek.krakow.pl/publikacja/proceedings.html (1.03.2016).

Hasik, W. (2015). Quality of financial information on solvency - the evidence from financial reporting practices of companies quoted on the Warsaw Stock Exchange. In: J. Krasodomska, K. Świetla (red.), Wspótczesne uwarunkowania sprawozdawczości i rewizji finansowej (s. 171-184). Kraków: online publication of UEK downloaded from: http://rachfin.uek.krakow.pl/publikacja/proceedings.html (1.03.2016)..

Ignatowski, R. (2011). Wykorzystanie koncepcji grup kapitałowych w regulacjach rachunkowości i ich wptyw na wysokość kapitałów prezentowanych w sprawozdaniach finansowych. Problemy Zarządzania, 9, 4 (34), 75-107.

Jurewicz, A., Walińska, E. (2008). Jakość informacji finansowej generowanej przez system rachunkowości. Zeszyty Teoretyczne Rachunkowości, 44 (100), 101-113.

Klimczak, M.K., Pikos, A., Dynel, M. (2015). Uncertainty in the financial statements: the study of goodwill disclosures in Polish. In: J. Krasodomska, K. Świetla (red.), Współczesne uwarunkowania sprawozdawczości $i$ rewizji finansowej (s. 217-226). Kraków: online publication of UEK downloaded from: http://rachfin.uek.krakow.pl/publikacja/proceedings.html (1.03.2016)..

Mućko, P. (2008). Koncepcja zmian w sprawozdawczości finansowej spółek publicznych. Szczecin: Wydawnictwo Uniwersytetu Szczecińskiego.

Walińska, E., Bek-Gaik, B., Gad, J., Rymkiewicz, B. (2015). Sprawozdawczość przedsiębiorstwa jako narzędzie komunikacji z otoczeniem. Wymiar finansowy i niefinansowy. Łódź: Wydawnictwo Uniwersytetu Łódzkiego.

\section{JAKOŚĆ INFORMACJI NT. PLYNNOŚCI - WYNIK EMPIRYCZNYCH BADAŃ SPÓŁEK NOTOWANYCH NA WARSZAWSKIEJ GIELDZIE PAPIERÓW WARTOŚCIOWYCH}

Streszczenie: $\mathrm{Cel}$ - celem artykułu jest diagnoza aktualnych praktyk sprawozdawczych polskich spółek notowanych na WGPW pod kątem oceny jakości informacji sprawozdawczych umożliwiających ocenę płynności jednostek sprawozdawczych. Artykuł prezentuje wyniki szerszego projektu badawczego nt. jakości sprawozdawczości finansowej spółek z warszawskiego parkietu głównego. Pierwsza część badań dotyczyła jakości informacji nt. wypłacalności. Metodologia badania - przeprowadzono empiryczne, jakościowe badania na próbie jednostkowych sprawozdań finansowych spółek z indeksu WIG 30 z wyłączeniem spółek z sektora finansowego. Wynik - autor dostarcza dowodów, że aktualne praktyki sprawozdawcze spółek w Polsce nie zapewniają interesariuszom wystarczających informacji finansowych potrzebnych do wiarygodnego określenia płynności jednostki gospodarczej, rozumianej i analizowanej w kontekście dynamicznym. Oryginalność/Wartość - autor prezentuje krytykę rzeczywistych praktyk sprawozdawczych polskich spółek na podstawie przeprowadzonych badań empirycznych, przyjmując perspektywę interesariusza jako punkt wyjścia do oceny jakości informacji sprawozdawczych. Aktualnie takie badania w Polsce są ciągle rzadkością, a dominuje nurt normatywny badań nad sprawozdawczością i rachunkowością finansową. 
Keywords: jakość informacji sprawozdawczej, płynność finansowa, praktyka sprawozdawczości, Warszawska Giełda Papierów Wartościowych

\section{Cytowanie}

Hasik, W. (2016). The quality of information on financial liquidity - empirical evidence from public companies quoted on Warsaw Stock Exchange. Finanse, Rynki Finansowe, Ubezpieczenia, 2/2 (80), $115-122$. DOI: 10.18276/frfu.2016.2.80/2-12; www.wneiz.pl/frfu. 